PROBLEMS

OF EDUCATION

IN THE $21^{\text {st }}$ CENTURY

Vol. 79, No. 1, 2021

\section{'LEARNING MOMENTS' AS INSPECTABLE PHENOMENA OF INQUIRY IN A SECOND LANGUAGE CLASSROOM}

\author{
Ricardo Moutinho, Andrew P. Carlin \\ University of Macau, Macau-SAR, China \\ Email: moutinho@um.edu.mo, acarlin@um.edu.mo
}

\begin{abstract}
Learning is an omnipresent feature of social life. However, in educational fields, learning is often studied through indirect instruments, such as surveys, interviews and coding schemes. In this paper, a praxiological approach to observe learning moments is proposed. This means that learning moments are not explored here through schematic reporting or statistical evaluations, but as accountable and inspectable phenomena as they became available in the corpus explored. Using a video-recorded fragment of interaction that occurred during a second language (L2) class in a primary school in Macau (China), the practical, collaborative instructed experiences of participants (teacher and students) in a lesson are analysed. It was observed that classroom participants attend to the categorial and sequential features of learning environments, which provide the contextual details that afford members' realization of phenomena as learning moments. Stated differently, learning moments should not be confused with the successful accomplishment of a lesson plan just to satisfy programmatic (and disciplinary) requirements, but as something produced and accountable by participants as learning in and through their very practices of concerted interaction. As learning moments are ubiquitous characteristics of educational environments, the discussion of the results has pedagogical implications for teacher training, and for the assessment of teaching.
\end{abstract}

Keywords: conversation analysis, ethnomethodology, learning moments, membership categorization, social competence, turn-allocated categories

\title{
Introduction
}

While studies of classroom interaction talk about 'learning moments', what may constitute a 'learning moment' is yet to be established. As suggested in this paper, learning moments have indexical properties, i.e. they are realized as learning moments within the contexts of their occurrence. Accordingly, learning moments must remain undefined, as learning is constituted by local contingencies during the process of its own production. Although this may be an unsatisfactory position for readers - a definition of the phenomenon of study is not forthcoming at the start of the paper - the reasons for not attempting to do so will be clarified when considering the uniqueness and unpredictable character of interactional events, and the intersubjective character of 'learning moments'.

A learning moment happens as 'another first time' (Garfinkel, 1967, p. 9), and each time that it is witnessable it emerges through (and under) different forms. As such, a definition of the phenomenon should not be provided at the outset, at the expense of actual instances that may fall outside formal definition; rather, analytic attention should focus upon the demonstration of its occurrence through members' practices. Such a procedure has precedent (Goodwin \& Duranti, 1992). Members make learning moments happen collaboratively and formulate these in situ. The specificities of a learning moment, according to members, provide for its definition.

Definitional problems have impacted upon the range of research that is available on learning moments. Learning moments, as critical incidents that provide opportunities for self- 
reflection, are mainstay features of teacher training programmes (Carlin \& Moutinho, 2020).

This study concerns the dynamic nature of learning moments, as characterized by participants, in the context of language learning in the primary sector.

There are significant implications of this study. The data (in video and transcript form) are from an understudied international context - Macau, a Special Admininistrative Region (SAR) of China. Further, among studies of second language learning, these data are unusual with Cantonese being the first language of the participants (L1), the target language (L2) is Portuguese. The rarity of such data should not deter wider lessons being learned, however, as the granular focus of the approach taken by this study is widely applicable to other teaching contexts. These data should not be taken as singular because the research approach concentrates on the practices of classroom interaction by teacher and students; in doing so, the study brings classroom interaction - specifically, learning moments appreciated by all teachers - into greater relief. Also, as detailed throughout the paper, the data established and regulated the terms of the analysis. That is, analysis follows the data rather than engaging in concept chasing for purposes of generalization, which ironically takes education studies further away from the phenomena they purportedly investigate.

\section{Research Problem}

In pedagogical literatures, learning moments have been 'registered' either through analysts' accounts or excerpts retrieved from interviews with teacher and students. There are examples of this in the field of medical education (Belliveau, 2007; Clavet et al., 2015; GilpinJackson, 2014; Pilcher, 2016; Smail et al., 2006; Tejura, 2015), while in other areas such as mathematics and artificial intelligence, learning moments are detectable through code systems combined with intelligent tutorial systems and/or statistical representations (Adamson et al., 2011; Bruce et al., 2011). However, there are two problems inherent in these approaches. First, they depend in entirety upon how an analyst defines a 'learning moment', a procedure that is inimical to the rigorous analysis of educational encounters. Second, they remove the 'learning moment' from the context of its occurrence, since the in vivo interactional work done by the participants is overlooked.

Therefore, a different (radical, praxiological) approach is proposed here to discuss learning moments. Using video data obtained from a primary school lesson in Portuguese as a second language, 'learning moments' are discussed in this study by examining how participants formulate and recognize the context in which learning moments may be occasioned. As language is a "typifying medium" and an "organized storehouse of common-sense knowledge of the society" (Watson, 2016), examples of how L2 classroom members orient to learning moments as natural facts of their everyday lives are explored. The data transcripts show how members formulate contexts of learning production while engaged in structured interactions. This means that classroom participants are interactionally 'tied', both sequentially and categorially, since they orient to a 'nextness' (Schegloff, 1992) of the activity, while at the same time they invoke certain categories (e.g. 'the best student') that help them identify each other and the learning moments that happen inside the classroom interactive space.

This research contributes to a better understanding of how learning takes place in language education environments and encourages language teachers to focus more on participants' practices, not only on theoretical representations of those practices.

\section{Research Focus: Approaches to Studying Classroom Environments}

Ethnomethodology (EM) and Conversation Analysis (CA) (Watson \& Gastaldo, 2015) have always regarded institutional practices of classroom environments as researchable matters 
PROBLEMS

OF EDUCATION IN THE $21^{\text {st }}$ CENTURY Vol. 79 , No. 1,2021

82

(Macbeth 2010; Watson, 1992). Studies using CA to inform second language acquisition (SLA) theories (Brouwer \& Wagner, 2004; Hall, 2018; Hellermann, 2018; Kasper, 2009; Markee \& Kasper, 2004) have also focused on evidence of language and social competences to identify learning moments in second language (L2) classrooms. The works of these scholars indicate that competence is not only observable by the learning of course content (delivered by the teacher), e.g. through sequences such as 'teacher's initiation-students' response' format or even by external standards produced beyond the local contingencies of the interaction. It is also possible to witness learning moments in data transcripts wherein 'members' (students and teachers) show themselves to be competent in the ongoing interactional production of the lessons (cf. Lee, 2006; Macbeth, 2010).

Scholars doing EMCA have tried to demonstrate empirically how people provide instructions and exhibit their practical and visible orientation to those instructions through the work of following them, i.e. what Garfinkel $(2002$, p. 105) termed "instructed actions" or, in this study, "instructed experience". Recently there have been studies available in EMCA literature on how students orient to a range of instructive phenomena related to the opening and closing of university lectures and seminars (Garfinkel, 2002; Tyagunova \& Greiffenhagen, 2017), to the manipulation of telescopes in astronomical observatories (Marques et al. 2020), to the identification of 'learnables' during surgery at a teaching hospital (Zemel \& Koschmann, 2014) and to the joint accomplishment by teachers and very young students of everyday activities such as pretend play episodes, managing disputes and talking about the environment (Bateman, 2015).

However, in the radical praxiological agenda of EMCA studies, so far no study has provided empirical analysis of learning moments with data gathered from L2 classroom environments. Some exceptions apply to studies that used CA to focus on the efficacy of pedagogical approaches and the development of specific language abilities to inform theories in the field of Second Language Acquisiton (e.g. Brouwer \& Wagner 2004; Hellermann, 2018; Kasper 2009; Markee 2004), but there are no examples of studies that took classroom members' visible recognition of a learning moment as the topic of inquiry, free from theoretical impositions or unspecified (and unspecifiable) abstractions.

Mehan (1984), for example, insisted on the idea that in educational environments the research focus should be placed upon the contextual use of language in action as carried out by participants. To do so, as Francis \& Hester (2004) argued, learning moments cannot be abstracted from the lived detail of their occurrence and then re-contextualized to corroborate or challenge programmatic assumptions.

Zemel and Koschmann (2014, p. 164) argued that 'learnables' "should not be confused with a lesson plan or a list of learning objectives". Although teachers do orient to such artefacts, these remain (what Garfinkel, 2002, called) 'docile texts', separate from the interactions that constitute the sessions which lesson plans and learning objectives inform. It is only through the lesson itself that the lesson plan and learning objectives can be realized. Lessons may be 'textually mediated' (Smith 1990) via teachers' orientation towards lesson plans and learning objectives, but the lesson plans and learning objectives are interactionally accomplished.

In a companion paper to this current empirical study, Carlin and Moutinho (2020) provided a conceptual discussion on teaching and learning moments and stated that those programmatic assumptions "have obscured the phenomenal integrity of the learning environment; since the topic sought is based on critical incidents according to analysts' interests" (Carlin \& Moutinho, 2020 , p. 1). Hence, the topic of study should be the actual identifying details of the setting as made available by the participants. We are careful to follow the data rather than engage in chasing concepts. This guards against incorporating seemingly useful concepts e.g. third turn or third position repair (Badem-Korkmaz \& Balaman, 2020; Schegloff 1997a), derived from different data sets, which do not fit our data. 
Learning happens in and through the everyday contingencies present in a language class and, as the video data and transcripts discussed in this paper show, learning and the local occasions of its production are naturally accountable to any member of that cohort, not only to the analyst. This means that it is not up to the analyst to decide what learning moments are, e.g. evidence that a student acquired some competence in the target language, but is up to participants to recognize learning at any point in a language class, made by the work of that cohort without following, proving, applying or criticizing theoretical assumptions. Classroom researchers cannot produce an adequate analysis of a phenomenon if they attempt - for ideological or theoretical reasons - to subvert (through misdescription) the actions of participants. Participants are "practical methodologists" (Garfinkel, 1967; Wowk, 1984), since they produce the contexts of actions and demonstrate their competence through such productions. A radical praxiological orientation is then necessary in order to account for the natural language phenomena under observation here.

This radical methodological orientation has implications for analysts when reporting their findings. According to Hellermann (2018, p. 51), "for EMCA researchers of language learning, it is a challenge not to be distracted by linguistic forms, even in the transcript of turns and sequence of turns, when we want to undertake action-oriented analyses of learning-asprocess". This challenge is due to the analyst's insistence in selectively reporting only what is 'meaningful' to corroborate theoretical formulations in a specific field. By doing this, data lose their indexical properties and become instead tools, freestanding semantic or cultural categories, which miss the haecceities (Garfinkel, 1967), that is, the distinctly identifying features of their production.

A transcribed extract retrieved from a second language (L2) class for primary students is used. The extract (separated into four tables for heuristic purposes of detailed discussion) was selected because the participants (teacher and students) were jointly invoking the category 'best student' by recognizing the contribution, at a particular moment, of one student as an instance of 'doing well', an expression commonly attached to the identification of a learning moment. Hence, the category 'best student' is an "occasion-relevant" category (Payne, 1976, p. 35) used by participants in that setting, which legitimizes this category being taken as an analytic focus.

\section{Research Aims}

A way to obtain analytic purchase on learning moments is not to remove them from the context, but to account for how participants in the setting itself orient to 'learning moments' (Carlin \& Moutinho, 2020). That means that no a priori positions or protocols for the detection of learning moments within the video and transcript data are used. More generally, and based on previous studies (Lindwall \& Lymer, 2011; Zemel \& Koschmann, 2014), learning moments are not codified as 'things' or 'products' in the materials analysed here. Instead, learning moments have to be considered as contingent features of interaction, that is, how participants themselves formulate the context for the production of these moments. Therefore, 'learning moments' are seen as intrinsically indexical, constituent features of the context in which they occur.

Context is not a reified interactive space but a co-produced setting constitutive of members' practices and orientation to the work being done to formulate a specific setting. Garfinkel and Sacks (2017) refer to the term 'member' as the mastery of natural language, as the competence to be 'engaged in the objective production and objective display of commonsense knowledge of everyday activities' (p. 163). This means that the competence to produce or formulate context of learning in a second language (L2) lesson is reflexively intertwined with the competence that one has to be a member in an L2 classroom. In other words, it is through members' practices that a context is invoked, and its maintenance is inextricably intertwined with members' competences. The aim of this research is to explicate how classroom participants are producing learning settings and achieving their goal set for specific lesson content. 
PROBLEMS

OF EDUCATION

IN THE $21^{\text {st }}$ CENTURY Vol. 79 , No. 1,2021

84

Research Methodology

\section{General Background}

The research analysis was based on a radical praxiological approach called Ethnomethdology and Conversation Analysis (EMCA), initiated by the studies of Garfinkel (1967) and further developed by other studies (Garfinkel, 2002; Garfinkel et al., 1981; Eglin, 1980; Pollner, 1979; Sacks et al., 1974; Schegloff, 1997b; Sharrock \& Watson, 1995; Watson 1994, 2015). In this approach, people's actions, which are preserved in the recordings, have prima facie properties, i.e. they provide sufficient corroborating evidence to support the discussion of the events that happen in social environments, including educational ones, such as language classrooms.

Following Macbeth (2001, p. 49), this research sought to describe "the situated production of order, discourse and action - and thus the teaching and learning that goes on there - as local ensembles of competent practice and practical orientations by students and teachers alike". This means that teacher and students need to learn how to act as 'classroom members' and the accounts that they provide - accounts witnessable in recordings of naturally occurring interaction within the classroom - show how competent they are in doing these classroomspecific activities.

The research focus was turned to an extract of classroom interaction data retrieved from a primary school lesson in Macau (China). The students were being taught Portuguese as an L2. All the participants (20 in total, including the teacher) were Macau Chinese locals and have Cantonese as their L1. The transcript of the extract (available in its full version in Appendix A) shows the teacher using a glove puppet ('Piggy') while working on a specific lesson content (teaching the expression "posso sair?" - may I leave? in the target language). The transcript is part of a database consisting of more than thirty lessons recorded in 2007 over the period of one semester in the same school (the transcription conventions are available in Appendix B).

The video-recorded data are presented as the class happened. The rigor of the analysis was assured through close transcription of the video, which afforded repeated attention to the temporality and granularity of events, ensuring that all participants' productions were accounted for and therefore available for analysis. As the research data of this paper shows, such classroomspecific competencies involve a witnessable orientation to "membershipping" activities (Payne, 1976). In cases of L2 classrooms, members also need to master this competence when using the target language, and each moment that they are seen to be doing this can be identified as a learning moment.

\section{Instruments and Procedures}

The video data collection followed institutional and funding agency protocols on research ethics. The school and parents authorized the recording in a TPA meeting. A camera was placed at the front of the classroom and was moved slightly by an assistant to capture all the actions carried out by the participants (students and teachers) during the activities. All the names used in the transcript data are pseudonyms. As mentioned early in the introduction, the analytic focus of this research is placed upon the category 'best student', which is a relational feature that teacher and students use in common for the identification of a learning moment.

\section{Data Analysis}

The 'best student' is a member's category, not an analyst's category, which is occasioned by and devised for the practical purposes of this class-specific activity. It is important, however, 
to discuss how the teacher oriented the students to the potential predicates of the category 'best student'. Note that the 'best student' here is mentioned between quotes because it is an indexical category. Not all the 'best students' are the same. They differ from class to class and from moment to moment depending on the people who are invoking them.

Looking at the transcribed extract available in Appendix A, it is possible to observe that, at line 8 , when the teacher says "o bin go zou dak zeoi hou ngo bei koei (.) lo go zyu zyu gong" (oh the best one gains the right to say it with piggy), she is indicating what the students must do in order to have the glove puppet in their hands, namely 'saying the sentence aloud in the target language that they are supposed to practice'. 'The best student' then becomes a salient category, and students are seen to be providing the teacher with some evidence that they are following her instructions and standing out among their classmates.

That is what is noticeable in Ernesto's performance, when he repeats the sentence given by the teacher louder and clearer than the rest of his classmates; notice how Ernesto initiates and closes the sentence at line 6 , while the rest of the class seems to be guided by him at line 7 . Following his subsequent participation (lines 12 and 14) within the cohort, the teacher (line 15) selects Ernesto as the 'best student'. This category is announced and invoked by the teacher at line 8 and grants him the right to operate 'Piggy'. This public acknowledgement of Ernesto's effort is a visible recognition that he has learned how to do the task. Therefore, a detection (by the teacher) of a learning moment is visible, which is a necessary phenomenon so that the instruction can move on to the next part.

Also, based on Watson's (1994) notion of turn-generated categories in public spaces, i.e. how queues are organized according to sequential and categorial local order productions, it is possible to see the inextricable relationship between sequence and categorization based on the teacher's selection of Ernesto as the 'the first student who gained the right to operate the puppet'. The teacher does this selection based on Ernesto's participation, i.e. display of learning at line 15, when he provided an account that supported her categorization and consequent turn allocation.

\section{Research Results}

\section{Turn-allocated Categories: 'The Best Student'}

The teacher's categorial work is described as using a 'turn-allocated category'. The teacher saw Ernesto's participation on that moment as a predicate of 'the best student', which was the salient action she needed to allocate the turn to someone. It is useful here to revisit turns 6-15 (Table 1), bringing the orderly, collaborative actions into greater relief. 
PROBLEMS

OF EDUCATION

IN THE $21^{\text {st }}$ CENTURY

Vol. 79 , No. 1, 2021

86 Table 1

\section{Excerpt (1): Searching for 'the best student'}

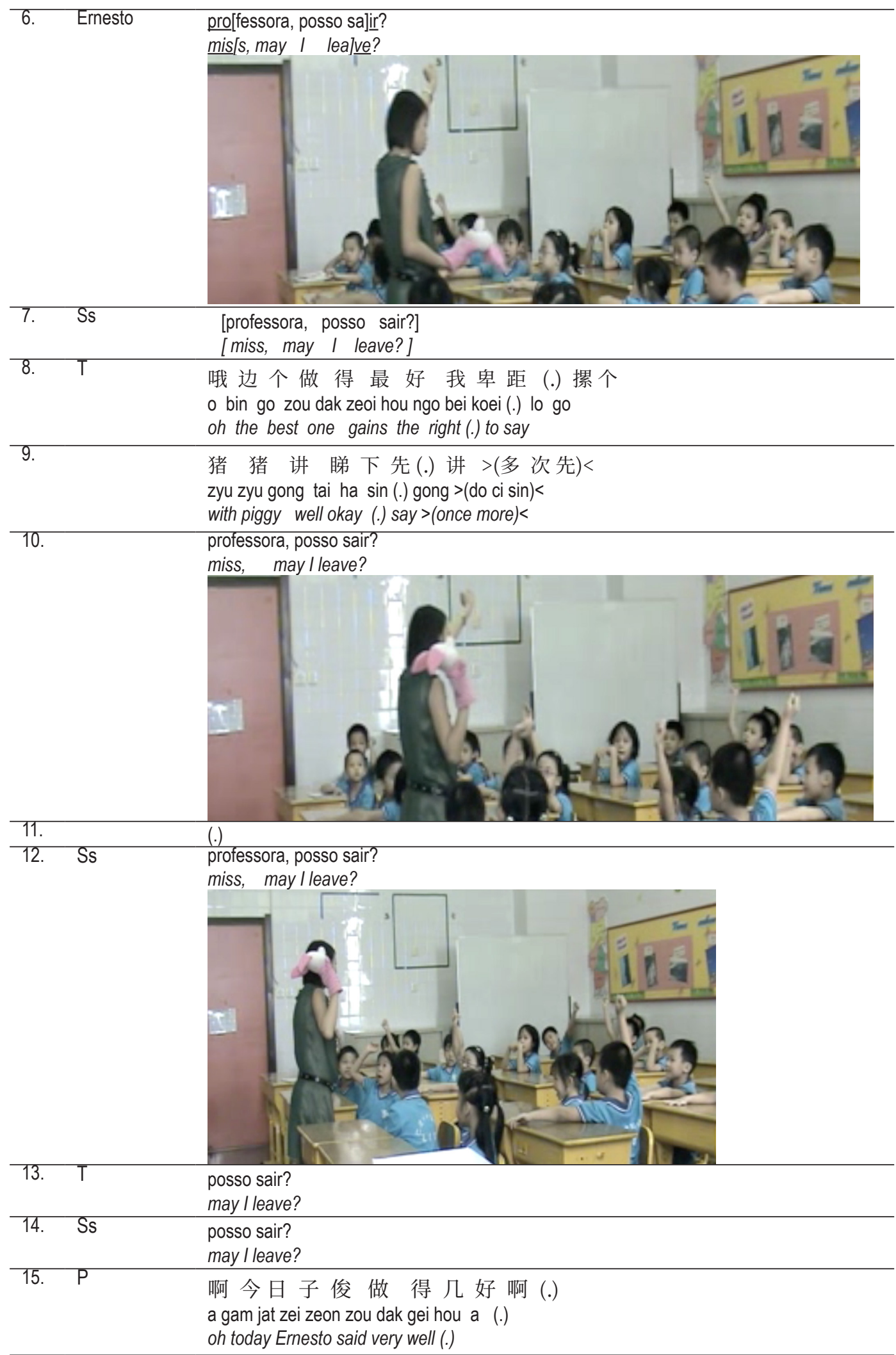


The teacher (indexed as " $\mathrm{T}$ " in the transcript) realized Ernesto's raised hand at line 6 earlier and finishes later than the joint turn taken by the rest of the class. It was an observablereportable feature, i.e. a member's matter, that Ernesto's participation stood out from what Macbeth (2000, p. 32) called the 'layered chorus' of his classmates' responses (lines 6-7).

When T said at line 15: "a gam yat zei zeion zou dak gei hou a" (oh today Ernesto said very well), she was identifying a moment where Ernesto had done well for the practical purposes to which the classroom members were oriented: to repeat a new sentence in the target language.

The use of "gam yat" (today) in this utterance produced by the teacher is heard as compared with its alternate "yat yat" (every day). This means that it was not possible to know if Ernesto was a student who did well every day, but at that moment he did something that could be seen as a predicate of 'the best student' for that specific moment. As mentioned earlier, the categorization of 'best student' is indexical since it does not have the same (that is, an objective and stable) meaning at all times. Ernesto was 'the best student of that class, at that particular moment'; Ernesto's classmates found actions that could serve as predicates of 'what being the best student' constituted for the task. From the video data it is possible to see that since they were all doing the same thing (saying the sentence aloud), the participants had no problem in realizing predicates of 'the best student' to be recognized as such. A methodical achievement on the part of all the participants (not only the teacher) was visible here, which in turn partially repairs the indexicality of the category 'best student' at that particular moment.

Consequently, 'the best student' was not necessarily a reference to the best in other classes or in other moments of the same class or the same course. 'The best student' was an occasioned category for the practical purposes of the task-at-hand, i.e. to learn how to say the sentence in the target language aloud. Ernesto was being categorized as 'the best student' at that moment no matter how another 'best student' could be so adjudged in another class. In short, this discussion does not judge the teacher's (and students') active selection of Ernesto as the best student but describes instead how they were jointly invoking this category.

\section{Demonstrating Competence to the Rest of the Class}

The teacher was using practical methods to identify moments where the students were showing instances of learning. When Ernesto showed that he learned how to produce the sentence that was being taught, he gained the opportunity to show his newly acquired competence to his classmates. The teacher's 'discovery' of a learning moment had a 'first time through' property and that the work that she and her students have been doing reveals the local formulation of the context of learning itself, through the haecceities of their 'self-same' working practices. Excerpt (2) (Table 2) highlights how the interaction unfolds subsequent to the production of a turn-allocated category, the identification of Ernesto as 'the best student'. 
Ricardo MOUTINHO, Andrew P. CARLIN. 'Learning moments' as inspectable phenomena of inquiry in a second language classroom

PROBLEMS

OF EDUCATION

IN THE $21^{\text {st }}$ CENTURY

Vol. 79 , No. 1, 2021

\section{Table 2}

Excerpt (2): Identifying Ernesto as 'the best student'

啊今日子俊 做 得几好啊 (.)

a gam jat zei zeon zou dak gei hou a (.)

oh today Ernesto said very well (.)

子俊 你试下 $(2.5)\left(\right.$ ) 讲 啊 $(.)^{\circ}$ 讲 啊 ${ }^{\circ}$

zei zeon nei si ha (2.5) ( )gong a (.) ${ }^{\circ}$ gong $a^{\circ}$

Ernesto try (2.5)( ) say it (.) ${ }^{\circ}$ say it ${ }^{\circ}$

\begin{tabular}{|c|c|}
\hline 11. & $\begin{array}{l}{ }^{\circ} \text { 讲 啊 }{ }^{\circ} \text { 你试一下伸入来讲 啊 } \\
{ }^{\circ} \text { gong } a^{\circ} \text { nei si jat ha san jap lei gong } A \\
{ }^{\circ} \text { say it } t^{\circ} \text { put your hand inside it and say it }\end{array}$ \\
\hline
\end{tabular}

\begin{tabular}{lll}
\hline 18. & Ernesto & $($ ) \\
\hline 19. & T & po: \\
& & ma:
\end{tabular}



\begin{tabular}{lll}
\hline 20. & $()$. \\
\hline 21. & Ernesto & po: \\
& & ma: \\
\hline
\end{tabular}

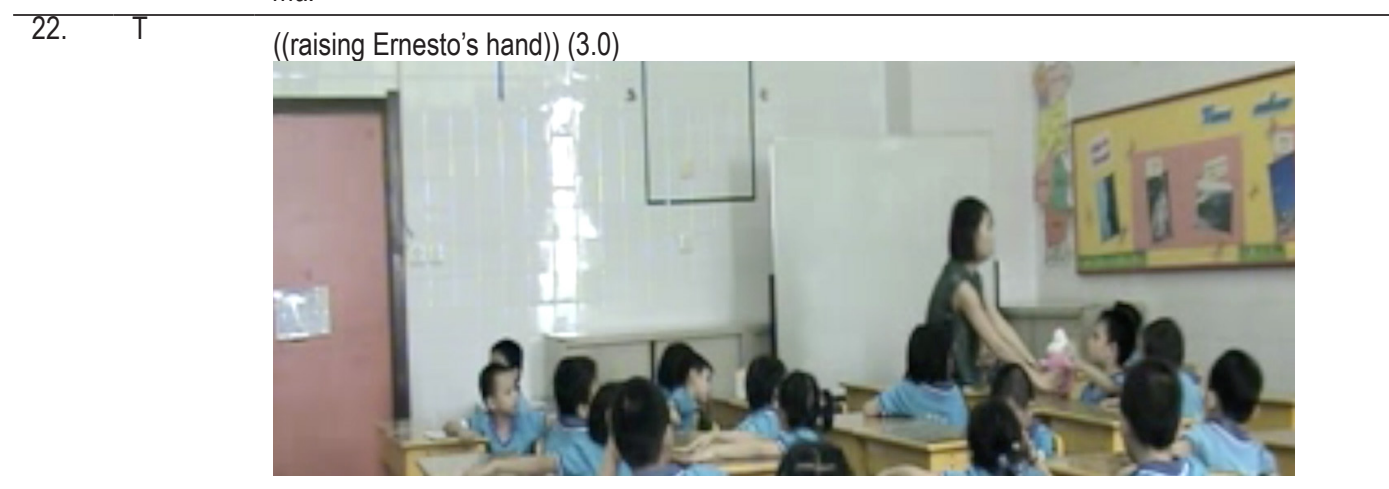

23.

哎呀哎呀唔记得左哦 (.) 点 讲 啊?

ai ya ai ya $\mathrm{m}$ gei dak zo o (.) dim gong a?

oh oh he forgot (.) how to say it?

\begin{tabular}{ll}
\hline $24 . \quad$ Joana & professora, posso sair? \\
& miss, may l leave?
\end{tabular}

When Ernesto was given the turn, he could not do what he was required to do (see lines 18-23). A problem then arose and the teacher (lines 16-17) repeated the instructions to Ernesto, in a simpler way this time, addressing him alone among his classmates "gong a ${ }^{\circ}$ gong ${ }^{\circ}{ }^{\circ}$ gong 
$\mathrm{a}^{\mathrm{o}}$ " (say $i{ }^{\circ}$ say $i t^{\circ}{ }^{\circ}$ say $\left.i t^{\circ}\right)$. When this was unsuccessful, she provided Ernesto with a more Vol. 79, No. 1, 2021 detailed instruction on how to perform the move (line 17) "nei si jat ha san jap lei gong A" (put your hand inside and say it), with a higher tone put in the utterance particle located at the end of her turn "A" (which has no equivalent English translation). The teacher designed her utterance to a specific recipient (Ernesto) here in a different way from what she was doing before, when she was addressing the whole class as a cohort. This work of producing a recipient designed utterance became even clearer when she approached Ernesto and twice provided the first bit of the sentence "po:" ( $\mathrm{ma}$ :) that he was required to say while operating the puppet (lines 19 and 21). With no response from Ernesto, the teacher approached the student again, raised his hand (on which he had the glove puppet) and waited for his utterance (see the screenshot at line 22). However, a three-second silence follows, and Ernesto seemed to be unable to repeat the sentence that he had been producing beforehand.

A closer look at the sequence, though, reveals what was going on. Ernesto was following the teacher's instructions through a combination of body movements and talk. When the teacher was asking the students to say "posso sair" (may I leave?), she was also raising her left hand at the same time. Ernesto and his fellow students were apparently following the teacher's moves as observable in the screenshot (Table 1, Excerpt 1, lines 6 and 10-12).

Nonetheless when Ernesto finally had 'Piggy' in his hand, what was he supposed to do? Was Ernesto the one supposed to say the sentence (with his hand raised), or 'Piggy'? In other words, did Ernesto have to 'talk as the puppet' when uttering the sentence, or did he have to repeat the sentence, as he was doing before? It seems that a coordination of talk and body movements was also necessary to accomplish the task this time. When following the teacher's move (screenshot at line 6), Ernesto was not raising his left, but right hand when saying the sentence. When the teacher approached him, though, she shoved the puppet on his right hand. As the puppet was on his right hand, should he raise the left hand instead to say the sentence?

Ernesto looked at the teacher, raised his left hand and started to utter the sentence, but withdraws twice (lines 19 and 21). As Ernesto was seated on his chair and raising his left hand, the puppet (in his right hand) was not visible to the other students anymore (see the screenshot at line 19). This caused another problem, which the teacher tried to repair by approaching Ernesto one more time, grabbing his right hand and raising the puppet (line 22). The difficulty then seemed not to be a problem of remembering the sentence, which the teacher suggests Ernesto had forgotten (line 23), but what embodied actions should be combined with the talk to operate the puppet and say the required sentence, at the same time.

Recognizing that Ernesto was not going to do the move, the teacher asked the help of the other students, who promptly said the sentence that Ernesto was unable to furnish (see Joana's action at line 24). At this moment, the teacher directed her attention to Gabriel and shoved the puppet on his hand (line 25). 
PROBLEMS

OF EDUCATION

IN THE $21^{\text {st }}$ CENTURY

Vol. 79 , No. 1, 2021

90

\section{Table 3}

Excerpt (3): Other students help Ernesto

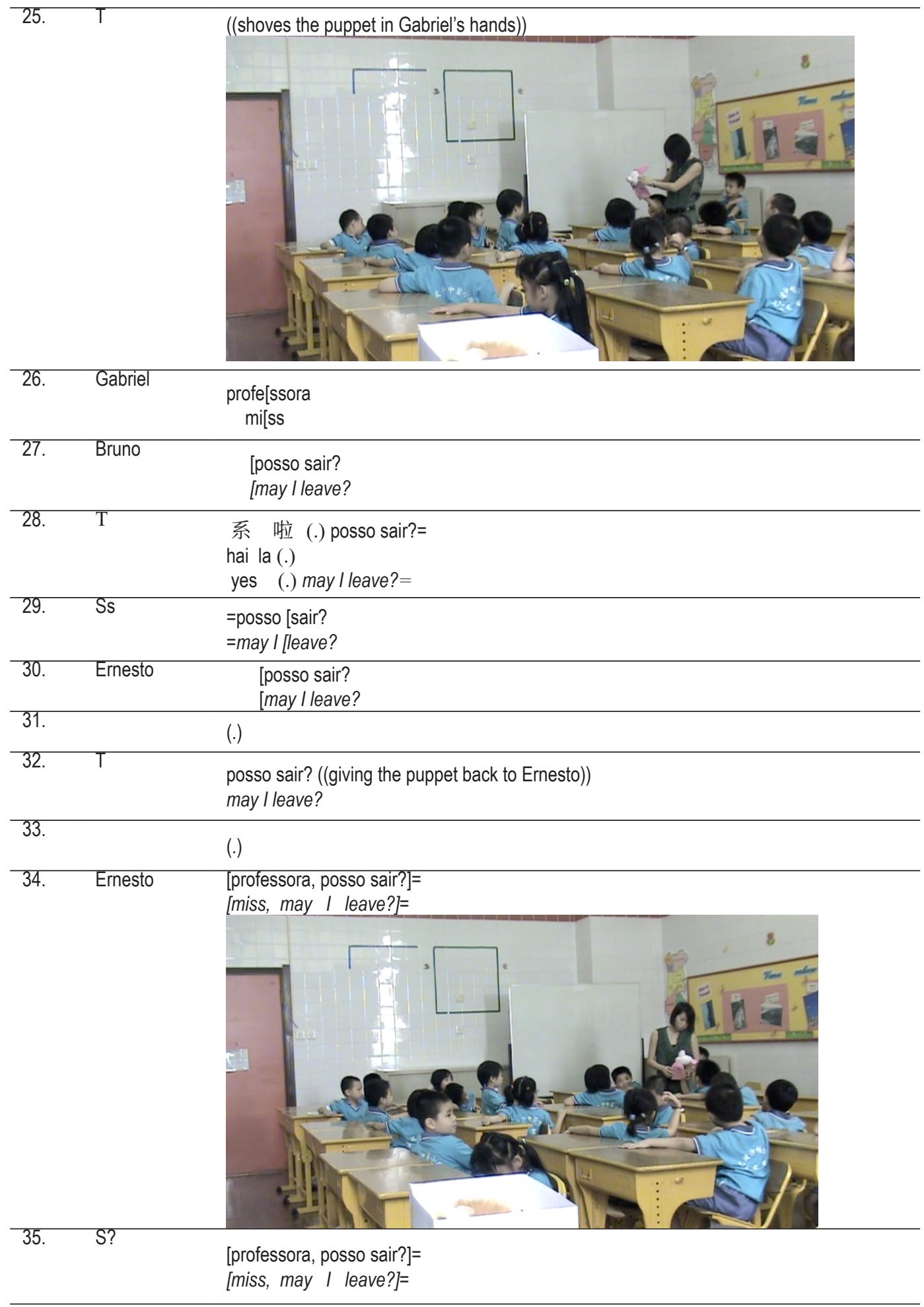


After observing Gabriel and his other colleagues (lines 27 and 29), Ernesto seemed to have understood the movements he was supposed to do while saying "posso sair"? as he performed this action without problems at line 34 (see screenshot). The other students showed competence to do the move that Ernesto was trying to do (combining the sentence with the necessary body work). This was an identification of a learning moment for the teacher since she seemed to be satisfied with her students' performance; and also, for Ernesto, as he could follow the actions of his classmates and subsequently be able to perform the task correctly.

Once Ernesto was done with his job, the teacher handed the puppet over to other students in a sequential order according to the physical arrangement of the rows. This is possible to observe through the screenshots below.

\section{Table 4}

Excerpt (4): The teacher hands the puppet over to other students in a sequential order

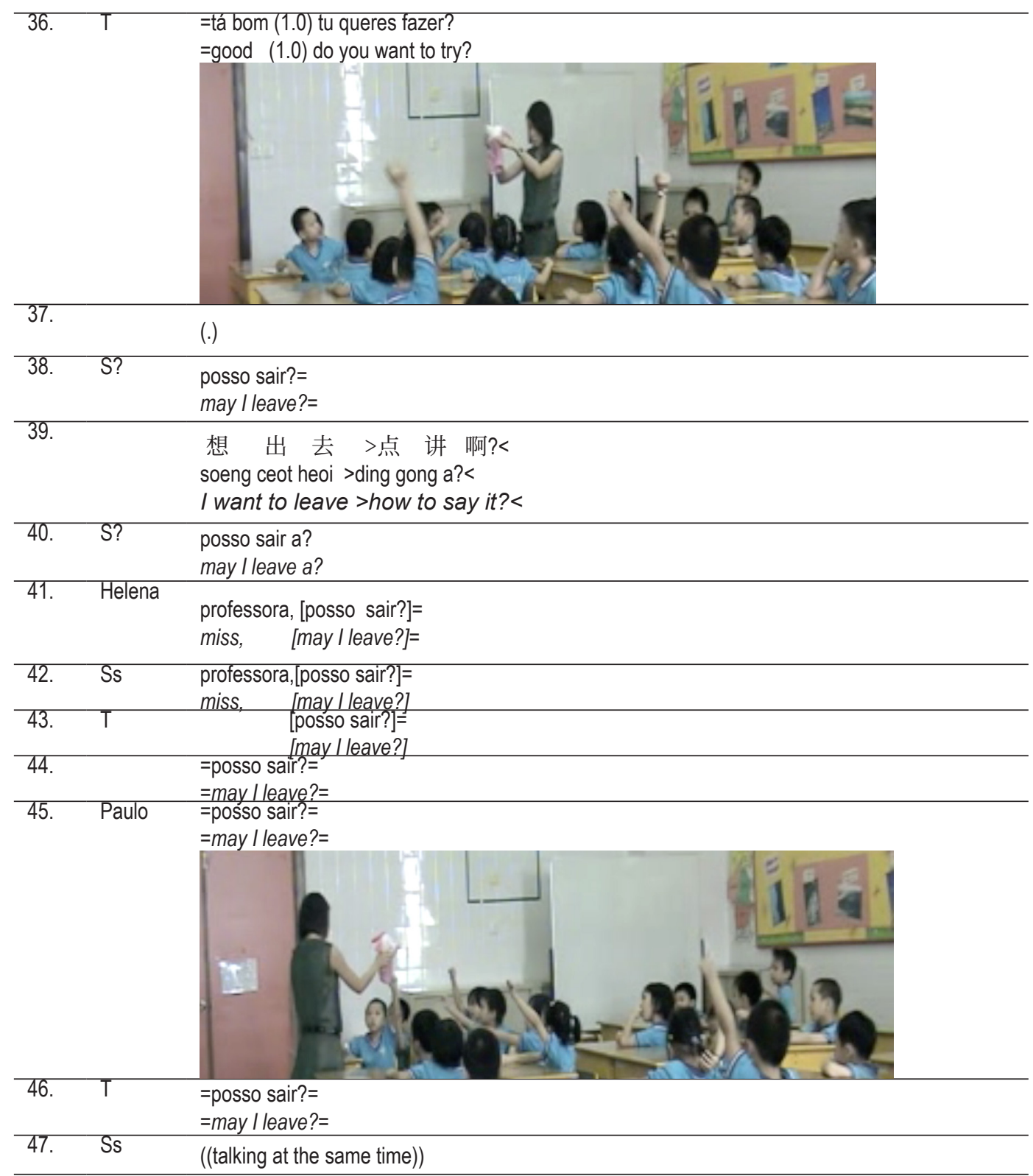


PROBLEMS

OF EDUCATION

IN THE $21^{\text {st }}$ CENTURY

Vol. 79, No. 1, 2021

92

The work produced by the students showed that they were orienting their actions to the sequence that the teacher was following. Once a learning moment was identified through the collaborative work of Ernesto, the teacher and some other fellow students, it now seems that the same work had to be reproduced by all the other students while operating the puppet in a sequential, organized manner.

\section{Discussion}

\section{Learning Moments as Explicative Transactions}

The methodical practices immanent within this sequence, as a series of learning moments, may be glossed as "explicative transactions", defined as an interactional event "in which what one does next will be seen as defining the import or significance of what another did before" (Pollner, 1979 p. 228). The salience of an interactional moment in classroom contexts, such as those under consideration in this paper, was thus not analytically defined but collaboratively produced, through the practices of seeing and members' work - students and teacher - in recognizing the relevance of what they have seen.

The "visibility criterion" that organizes explicative transactions was important to the procedure students were using to make adequate sense of what was going on. Although it was not possible to represent this phenomenon fully in the transcript, only the students who were close to the teacher were bidding for the turn, while others sitting farther away waited without raising their hands. As such, students seemed oriented to a categorially textured relevance space within the ecology of the classroom: the teacher and the prospect of taking a turn were too far away. Immediately after Ernesto's turn was over, the teacher opened the floor by passing the puppet to the students seated close to Ernesto (except Gabriel, who already had the chance to practice the sentence with 'Piggy' at line 26). T started this sequence through the question "tu queres fazer?" - do you want to try? (line 36) while giving the puppet to Helena; when that happened, students started to bid for turns by raising their hands (see the screenshot at line 36).

That means that the question "tu queres fazer?" at line 36 did not have a sense only to Helena (the recipient of the question), but to the whole class as a cohort. Furthermore, each member of that cohort could competently recognize the relevance of this question, and the state of orderliness it required. What that meant here is that the teacher did not need to say in so many words what each student had to do when operating 'Piggy'. She did not need, for example, to repeat the question "tu queres fazer?" every time a student had completed his/her turn. As a series of explicative transactions, students saw what constituted the successful completion of the task by watching previous students' attempts at repeating "posso sair" and monitoring the teacher's response to the repetition in combination with the operation of 'Piggy'. It is possible to see how the puppet was passed over to Paulo (line 45) without the need to ask him if he was up to operating it. Paulo already had his hand raised by the time when the teacher was passing near his seat.

This orientation shows that students knew the sequence of the activity, which delineated a proximate relevance space for potential turns with the puppet. They could see what would come next (a chance to try the sentence with 'Piggy'). At that moment, they knew all the students (regardless of how they were categorially defined, e.g. as 'good' or 'not good' students) would be given a chance to operate 'Piggy', and all they had to do was wait for their chance as soon as their classmate successfully completed his/her turn.

The order of the lesson changed, and the participants were visibly orienting to this new arrangement. However, such an activity was not an easy task, since it required the mastery of certain aspects recognizable to the members of that setting. If a participant is able to follow these aspects, he/she proves to be a 'member' of that setting since he/she can orient to the same 
world known in common and taken for granted (Schutz, 1962), to which any other member is also orienting towards. This means that interactions in the classroom analysed here were both sequentially and categorially structured.

An example of this structured organization happened when students had to wait for their colleagues to say the sentence correctly (in the target language) while operating 'Piggy' in an 'acceptable manner' (raising the puppet so that everybody could see it and move its arms and head while talking). Only after the move was over, could students bid for turns to have a go. For this reason, they had to be able to recognize (sequentially) when was a suitable moment to do that. This shows how competent they were in following what was going on. They were showing that they mastered all the conditions necessary to be in incumbent of the category 'student of that class' at that specific moment. They could understand the instructions given by the teacher, acknowledge the appropriateness of a sentence uttered in the target language, and recognize (and reproduce) the correct way to operate the object ('Piggy') they had in their hands.

In order words, that happened as 'another first time' since the students were being taught a new sentence in the target language and manipulating an object that they had never manipulated before. Every time the teacher passed the puppet over to the next student, she was also recognizing that the students were doing the activity correctly. If something went wrong (as seems to have happened at line 39), the teacher would stop the sequence and make a formulation so that the student could give the answer ("soeng ceot heoi $>$ ding gong a? $<$ " I want to leave $>$ how to say it? $<$ ). Only when a student said the sentence correctly while manipulating 'Piggy', would the teacher resume the sequence.

Therefore, the continuation of the sequence was dependent on the recognition of a learning moment, which is in line with what Zemel and Koschmann (2014, p. 165) argued in their study: "the instructee's enactment becomes a learnable as the instructor endorses the instructee's enactment". This has shown how a learning moment was an interactional accomplishment and how teacher's and students' actions were interactionally paired to make it happen.

\section{Searching for Learning Moments}

Learning moments and their affordances, both for self-reflection and classroom instruction, are matters that are upgraded particularly for the production of instructional materials for trainee and novitiate practitioners. However, as discussed in the introductory part of this paper, the prevailing orientation to learning moments as an analytic category must be problematized, since this approach is dependent upon treating learning events outside the context of their occurrence.

The search for learning moments produces a distorted approach to the proceedings of classroom environments in two, related ways: first, it isolates a 'segment' from its original context, depriving it of its meaning to participants and artificially attaching a new meaning to it as part of a collection. Second, it overlooks the 'surrounding' accomplishments of members displaying their competent orientation towards an institutionally defined setting. According to McHoul and Watson (1984, p. 299), "(a)ll too often, the 'routine' is glossed over in favour of the 'remarkable' precisely because it is routine-thereby ignoring its essential complexity and artfulness".

As Hemmings et al. (2000) suggested, classrooms are physically and textually structured interactive environments, where teachers and students work collaboratively to produce educational experiences. Therefore, tasks are locally and interactively achieved by the participants, thus educational experiences are accountable. However, Hemmings et al. (2000) raised an important question: to what extent do these accounts really represent moments of learning? Teachers know that learning moments become visible, hence inspectable-observable, and thereby potentially analysable in the practices that comprise the familiar, in situ efficacy 
PROBLEMS

OF EDUCATION IN THE $21^{\text {st }}$ CENTURY Vol. 79 , No. 1,2021

94

of their students' day's work. In other words, teachers can identify learning as phenomena, as 'results' of successfully accomplished practices that are formulated for pedagogical purposes. These phenomena are part of teachers' routine and the ultimate goal in any course. Then it is necessary to know how it is possible to identify these moments as constitutive of 'educational achievements' in a way that they represent a gain in practical terms of what participants are competent to do through the course of a certain activity. To approach this issue, though, requires consideration of 'learning'.

Whereas 'Vygotskian' learning is the result of the work of experts (teachers) in orienting novices (students) to acquire a specific content set for the lesson or course, this conception has little to add on how learning is achieved as a concrete, localized phenomenon. From this theoretical conception of learning, the success of educational processes is based on the idealization of teachers' best practices, e.g. how to make-effective use of classroom resources. Using an aprioristic determination of what learning looks like, such theoreticized approaches treat learning as a reified phenomenon. This aprioristic determination or 'motivated looking' misses the particulars of the very learning moment, the methods participants use as interactions unfold and make learning happen for that specific situation, as 'another first time' (Garfinkel, 1967, p. 9). Theorizing has little to offer regarding the immediacy and inspectability of learning in and as the work done by classroom members.

This research proposed, instead, an "unmotivated" look at learning, which facilitated approaching learning as the acquisition and mastery of practices done to accomplish certain tasks in the classroom interactive space. From this approach, learning moments could not be identified only by the analyst, but were first and foremost members' practices, produced for and recognized by classroom participants, which were in turn constitutive of methods that classroom participants used for producing consistency, coherence and other properties of individual and concerted actions (Garfinkel \& Sacks, 2017, p. 349) within the classroom.

As argued elsewhere (Lindwall \& Lymer, 2008), studies on 'learning moments' available in the literature so far have focused upon critical incidents at the expense of the normal, procedural work done by all participants in the learning environment as a recognizable state of affairs, as "the unremarkable coherence and familiar sense of everyday life" (Macbeth, 1991, p. 283). In order to go beyond an approach that fragments courses of action into critical incidents, it is necessary to focus on the massively observable work of classroom members as a 'gestalt' (Gurwitsch, 1964). 'Gestalt' analysis requires that a phenomenon cannot be excised from its context and then partitioned to attend to different analytical orientations.

The "gestalt-contexture" of the classroom requires data records and data analyses that address the interaction as produced by all its participants. Furthermore, the analysis was attuned not solely to the sequential environment - what Eglin (1980) called the 'local ecology' of the setting - but to the categorial environment also (Moutinho, 2019). Participants in the setting experienced interactional sequences and categorization activities at the same time, within a gestalt, so a credible analysis is one which looks at both sequential and categorial features as inextricably connected and 'reflexively tied' (Watson, 1997) rather than artificially separating one gestalt from another. Crucially, addressing these data from a consistent methodological approach - without conflating different paradigmatic priorities - avoided the production of 'category-errors' (Ryle, 1966).

The concern of this research with learning moments was one that is shared by all educationalists - regardless of perspectival orientations, methodological preferences, and theoretical allegiances - and it is possible that most of the readers will, at some time in their practice, be party to the analytic opportunities and restrictions that the considerations of this paper implicate. If an overview of education fields exhibits the generic relevance of opportunities for instruction in the form of 'critical incidents' (Biggs \& Tang 2011), with a fieldspecific gloss of 'learning moments', this paper argued that the concern to identify 'learning 
moments' wrenches such analytically-defined segments of an interactional event from their

original contexts, to create collections of naturally organized instances that may be inspected for pedagogic potential.

In this paper classrooms were seen as 'perspicuous settings' (Garfinkel, 2002), in which learning moments were occasioned in and as of the work by the participants, by their interactional practices, and not by the analyst's theoretical view on the phenomenon. Garfinkel et al. (1981) saw those practices as "extracting an animal from the foliage" (p. 132), where " $(\mathrm{t})$ he 'foliage' was the local historicity of their embodied shop practices. The 'animal' was that local historicity done, recognized, and understood as a competent methodical procedure". In the classroom situation analysed here, the 'animal' being 'extracted from the foliage' was the participants' competent practices in producing and identifying instances of learning as the produced practical observability of their ordinary classroom work.

\section{Conclusions and Implications}

In this research, a praxiological approach to learning moments was proposed. The main significance of this study was that learning moments were explored as accountable and inspectable phenomena as they became available in the corpus explored. Hitherto in the educational literature, such an approach to analyse learning has not yet been applied to data gathered in L2 classrooms. Another relevance of this study is to encourage language teachers to reorient towards participants' practices in an L2 class as demonstrations of members' competencies. Moreover, that those competencies can be recognized as having a definite, sensible and methodical character, which are specifically related to the tasks that students are assigned. In so doing, students may be recognized as capable of 'doing' learning through many 'unnoticed ways', but which become available, thereby inspectable, through close observation.

Educators across sectors are affected by the practice-based notion of 'learning moments'. However, the discussion of learning moments requires detailed analysis of sequential and categorial features of interaction settings. This means that considerations of learning moments have to be located as naturally organized activities; and, rather than treated as isolable incidents, these should remain contextualized within a learning occasion as a course of action.

The analysis presented here has pedagogical implications for teacher training, and for the assessment of teaching. A fully contextualized analysis, i.e. an analysis that attends to the gestalt-contextures of a lesson in terms of how its participants produce the setting, highlights the categorial and sequential practices that participants use as learning moments are occasioned and recognized. Practitioner oriented training programmes and teacher training resources need to account for the intrinsically contextual features of learning moments if they are to remain useful as a pedagogic concept.

As members produce context, they also produce phenomena observable in that context. Consequently, learning moments cannot be theoretically prescribed, organized for administrative or institutional convenience, nor considered as putative phenomena without analysis of members' practices; learning moments, as contextual phenomena, are not available a priori or at an analyst's insistence. They are 'talked into being' by members and can only become available to the analyst through the actions preserved in the recordings. Phenomena under scrutiny must then be observed and discussed 'from within', since it is 'from within' that context emerges and becomes an inspectable locus of practice.

\section{Acknowledgements}

This work was supported by the Macau Science and Technology Development Fund (FDCT) grant \# 0054/2019/A1. This study uses video data from the project "Interactions in 
PROBLEMS

OF EDUCATION

IN THE $21^{\text {st }}$ CENTURY Vol. 79 , No. 1, 2021

96

Portuguese as a Foreign Language classrooms and the building of contextual competence" coordinated by Roberval Teixeira e Silva (University of Macau). We thank him for permission to use these data.

\section{References}

Adamson, D., Bharadwaj, A., Singh, A., Ashe, C., D. Yaron, \& Rosé, C. P. (2014). Predicting student learning from conversational cues. In S. Trausan-Matu, K. E. Boyer, M. Crosby, \& K. Panourgia (Eds.), Intelligent tutorial systems: $12^{\text {th }}$ international conference ITS 2014 (pp. 220-229). Springer . https://doi.org/10.1007/978-3-319-07221-0

Badem-Korkmaz, F., \& Balaman, U. (2020). Third position repair for resolving troubles in understanding teacher instructions. Linguistics \& Education, 60. Article 100859. https://doi.org/10.1016/j.linged.2020.100859

Bateman, A. (2015). Conversation analysis and early childhood education. Ashgate. https://doi. org/10.4324/9781315574158

Belliveau, G. (2007). An alternative practicum model for teaching and learning. Canadian Journal of Education, 30(1), 47-67. https://doi.org/10.2307/20466625

Biggs, J., \& Tang, C. (2011). Teaching for quality learning at university (4 $4^{\text {th }}$ ed.). McGraw Hill.

Brouwer, C., \& Wagner, J. (2004). Developmental issues in second language conversation. Journal of Applied Linguistics, 1(1), 29-47. 10.1558/japl.1.1.29.55873

Bruce, C. D., McPherson, R., Sabeti, F. M., \& Flynn, R. (2011). Revealing significant learning moments with interactive whiteboards in Mathematics. Journal of Educational Computing Research, 45(4), 433-454. https://doi.org/10.2190/EC.45.4.d

Carlin, A. P., \& Moutinho, R. (2020). Teaching and learning moments as subjectively problematic: Foundational assumptions and methodological entailments. Educational Philosophy \& Theory. Article 1848536. https://doi.org/10.1080/00131857.2020.1848536

Clavet, D., Antao, V., Koppula, S., \& Walsh, A. A. (2015). Transform a teaching moment into your own learning moment: Fundamental teaching activities framework. Canadian Family Physician, 61(10), e464-e488. https://www.cfp.ca/content/cfp/61/10/e484.full.pdf

Eglin, P. (1980). Culture as method: Location as an interactional device. Journal of Pragmatics, 4(2), 121-135. https://doi.org/10.1016/0378-2166(80)90049-1

Francis, D. J., \& Hester, S. 2004. An invitation to ethnomethodology: Language, society and education. SAGE. http://dx.doi.org/10.4135/9781849208567

Garfinkel, H. (1967). Studies in ethnomethodology. Polity Press.

Garfinkel, H. (2002). Ethnomethodology's program: Working out Durkheim's aphorism. Rowman \& Littlefield.

Garfinkel, H., Livingston, E., \& Lynch, M. (1981). The work of a discovering science construed with materials from the optically discovered pulsar. Philosophy of the Social Sciences, 11(2), 131-158. https://doi.org/10.1177/004839318101100202

Garfinkel, H., \& Sacks, H. (2017). On formal structures of practical actions. In H. Garfinkel (Ed.), Ethnomethodological studies of work (pp. 160-193). Appleton-Century-Crofts.

Gilpin-Jackson, Y. (2014). Resonance as transformative learning moment: The key to transformation in sociocultural and posttrauma contexts. Journal of Transformative Education, 12(1), 95-119. https://doi.org/10.1177/1541344614541547

Goodwin, C., \& A. Duranti (1992). Rethinking context: An introduction. In A. Duranti \& C. Goodwin (Eds.), Rethinking context: Language as an interactive phenomenon (pp. 1-42). Cambridge University Press.

Gurwitsch, A. (1964). The field of consciousness. Duquesne University Press.

Hall, J. K. (2018). From L2 interactional competence to L2 interactional repertoires: Reconceptualising the objects of L2 learning. Classroom Discourse, 9(1), 25-39. https://doi.org/10.1080/19463014.2018.1433050

Hellermann, J. (2018). Languaging as competence: Considering language learning as enactment. Classroom Discourse, 9(1), 40-56. https://doi.org/10.1080/19463014.2018.1433052 
Hemmings, T., Randall, D., Marr, L., \& Francis, D. (2000). Task, talk and closure: Situated learning and the use of an 'interactive' museum artifact. In S. Hester \& D. Francis (Eds.), Local educational order (pp. 223-244). John Benjamins. https://doi.org/10.1075/pbns.73.09hem

Kasper, G. (2009). Locating cognition in second learning interaction and learning: Inside the skull or in public view? International Review of Applied Linguistics, 47, 13-16. https://doi.org/10.1515/iral.2009.002

Lee, Yo-An. (2006). Towards respecification of communicative competence: Condition of L2 instruction or its objective? Applied Linguistics, 27(3), 349-376. https://doi.org/10.1093/applin/aml011

Lindwall, O., \& Lymer, G. (2008). The dark matter of lab work: Illuminating the negotiation of disciplined perception in mechanics. Journal of the Learning Sciences, 17, 180-224. https://doi.org/10.1080/10508400801986082

Lindwall, O., \& Lymer, G. (2011). Uses of 'understand' in science education. Journal of Pragmatics, 43(2), 452-474. https://doi.org/10.1016/j.pragma.2010.08.021

Macbeth, D. (1991). Teacher authority as practical action. Linguistics \& Education, 3, 281-313. https://doi.org/10.1016/0898-5898(91)90012-8

Macbeth, D. (2000). Classrooms as installations: Direct instruction in the early grades. In S. Hester \& D. Francis (Eds.), Local educational order (pp. 21-72). John Benjamins. https://doi.org/10.1075/pbns.73.03mac

Macbeth, D. (2001). On 'reflexivity' in qualitative research: Two readings, and a third. Qualitative Inquiry, 7, 35-68. https://doi.org/10.1177/107780040100700103

Macbeth, D. (2010). Ethnomethodology in education research. In P. Peterson, E. Baker, \& B. McGaw (Eds.), International encyclopedia of education (Vol. 6, pp. 392-400). Elsevier. https://doi.org/10.1016/b978-0-08-044894-7.01538-4

Markee, N., \& Kasper, G. (2004). Classroom talks: An introduction. The Modern Language Journal, 88(4), 491-500. https://doi.org/10.1111/j.0026-7902.2004.t01-14-.x

Marques, J. B. V., Carlin, A. P., \& Moutinho, R. (2020). Seeing by proxy: A detailed analysis of an education interaction at the telescope. Revista Brasileira de Ensino de Física, 42. https://doi.org/10.1590/1806-9126-rbef-2019-0354

McHoul, A. W., \& Watson, R. (1984). Two axes for the analysis of 'common sense' and 'formal' geographical knowledge in classroom talk. British Journal of Sociology of Education, 5, 281-302. https://doi.org/10.1080/0142569840050305

Mehan, H. (1984). Language and schooling. Sociology of Education, 57(3), 174-183. https://doi.org/10.2307/2112601

Moutinho, R. (2019). Context formulation and the invocation of membership categories in an L2 classroom. Journal of Pragmatics, 140, 100-111. https://doi.org/10.1016/j.pragma.2018.12.002

Payne, G. C. F. (1976). Making a lesson happen: An ethnomethodological analysis. In M. Hammerseley \& P. Woods (Eds.), The process of schooling: A sociological reader (pp. 33-40). Routledge \& Kegan Paul.

Pilcher, J. W. (2016). Exploration of learning strategies associated with aha learning moments. Journal of Nurses in Professional Development, 32(2), 74-79. https://doi.org/10.1097/nnd.0000000000000233

Pollner, M. (1979). Explicative transactions: Making and managing meaning in traffic court. In G. Psathas (Ed.), Everyday language: Studies in ethnomethodology (pp. 227-255). Irvington.

Ryle, G. (1966). The concept of mind. Penguin.

Sacks, H., Schegloff, E. A., \& Jefferson, G. (1974). A simplest systematics for the organization of turntaking for conversation. Language, 50(4), 696-735. 10.1353/lan.1974.0010

Schegloff, E. A. (1992). In another context. In A. Duranti \& C. Goodwin (Eds.), Rethinking context: Language as an interactive phenomenon (pp. 191-227). Cambridge University Press.

Schegloff, E. A. (1997a). Third turn repair. In G. R. Guy, C. Feagin, D. Schiffrin \& J. Baugh (Eds.) Towards a social science of language (Vol. 2, pp. 31-40). John Benjamins. https://doi.org/10.1075/cilt.128.05sch

Schegloff, E. A. (1997b). Whose text? Whose context? Discourse \& Society, 8(2), 165-187. https://doi.org/10.1177/0957926597008002002

Schutz, A. (1962). The problem of social reality: Collected papers I. Martinus Nijhoff.

Sharrock, W., \& Watson, R. (1985). 'Reality construction' in L2 simulations. System, 13(3), 195-206. https://doi.org/10.1016/0346-251X(85)90033-8 
Ricardo MOUTINHO, Andrew P. CARLIN. 'Learning moments' as inspectable phenomena of inquiry in a second language classroom

PROBLEMS

OF EDUCATION

IN THE $21^{\text {st }}$ CENTURY Vol. 79 , No. 1, 2021

98

Smail, S., Hayes, T. \& Pugsley, L. (2006). How to make the most of learning moments and hot reviews. Education for Primary Care, 17(2), 171-173. https://doi.org/10.1080/14739879.2006.11864055

Smith, D. E. (1990). Texts, facts and femininity. Routledge. https://doi.org/10.4324/9780203425022 Tejura, N. (2015). Contact/Isolation. Academic Medicine, 90(1), 23-24. https://doi.org/10.1097/acm.0000000000000561

Tyagunova, T., \& Greiffenhagen, C. (2017). Closing seminars and lectures: The work that lecturers and students do. Discourse Studies, 19(3), 314-340. https://doi.org/10.1177/1461445617701992

Watson, R. (1992). Ethnomethodology, conversation analysis and education: An overview. International Review of Education, 38(3), 257-274. https://doi.org/10.1007/bf01101432

Watson, R. (1994). Catégorization, séquentialité et ordre social: Un nouveau regard sur l'oeuvre de Sacks. In L. Quéré \& J. Widmer (Eds.), L'Enquête sur les catégories de Durkheim à Sacks (pp. 151184). Éditions de l'École des Hautes Études en Sciences Sociales. https://doi.org/10.4000/books. editionsehess. 10027

Watson, R. (1997). Some general reflections on 'categorization' and 'sequence' in the analysis of conversation. In S. Hester \& P. Eglin (Eds.), Culture in action: Studies in membership categorization analysis (pp. 49-75). University of Philadelphia Press.

Watson, R. (2015). De-reifying categories. In R. Fitzgerald \& W. Housley (Eds.), Advances in membership categorization analysis (pp. 24-49). Sage. https://dx.doi.org/10.4135/9781473917873.n2

Watson, R. (2016). Harold Garfinkel and pragmatics. In Jan-Ola Östman \& J. Verschueren (Eds.), Handbook of pragmatics, 20, (pp. 1-64). John Benjamins. https://doi.org/10.1075/hop.20.gar1

Watson, R., \& Gastaldo, É. (2015). Etnometodologia \& análise da conversa [Ethnomethodology \& conversation analysis]. Vozes/Puc-Rio.

Wowk, M. T. (1984). Ethnographic inquiries: Practical and professional. Social Analysis, 16, 91-107. https://www.jstor.org/stable/23169315

Zemel, A., \& Koschmann, T. (2014). 'Put your fingers right in here': Learnability and instructed experience. Discourse Studies, 16(2), 163-183. https://doi.org/10.1177/1461445613515359

\section{Appendix A - Transcribed Extract}

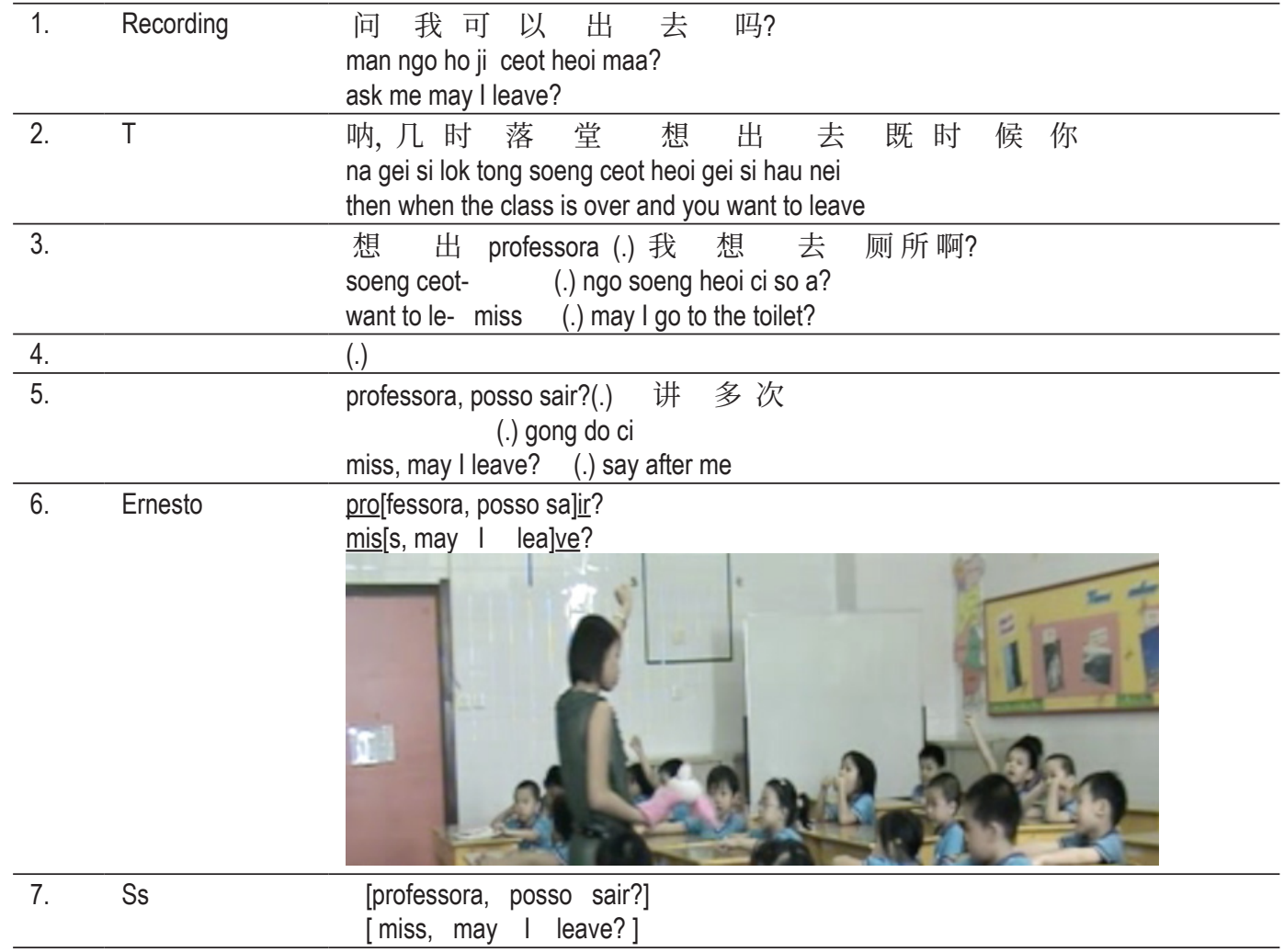




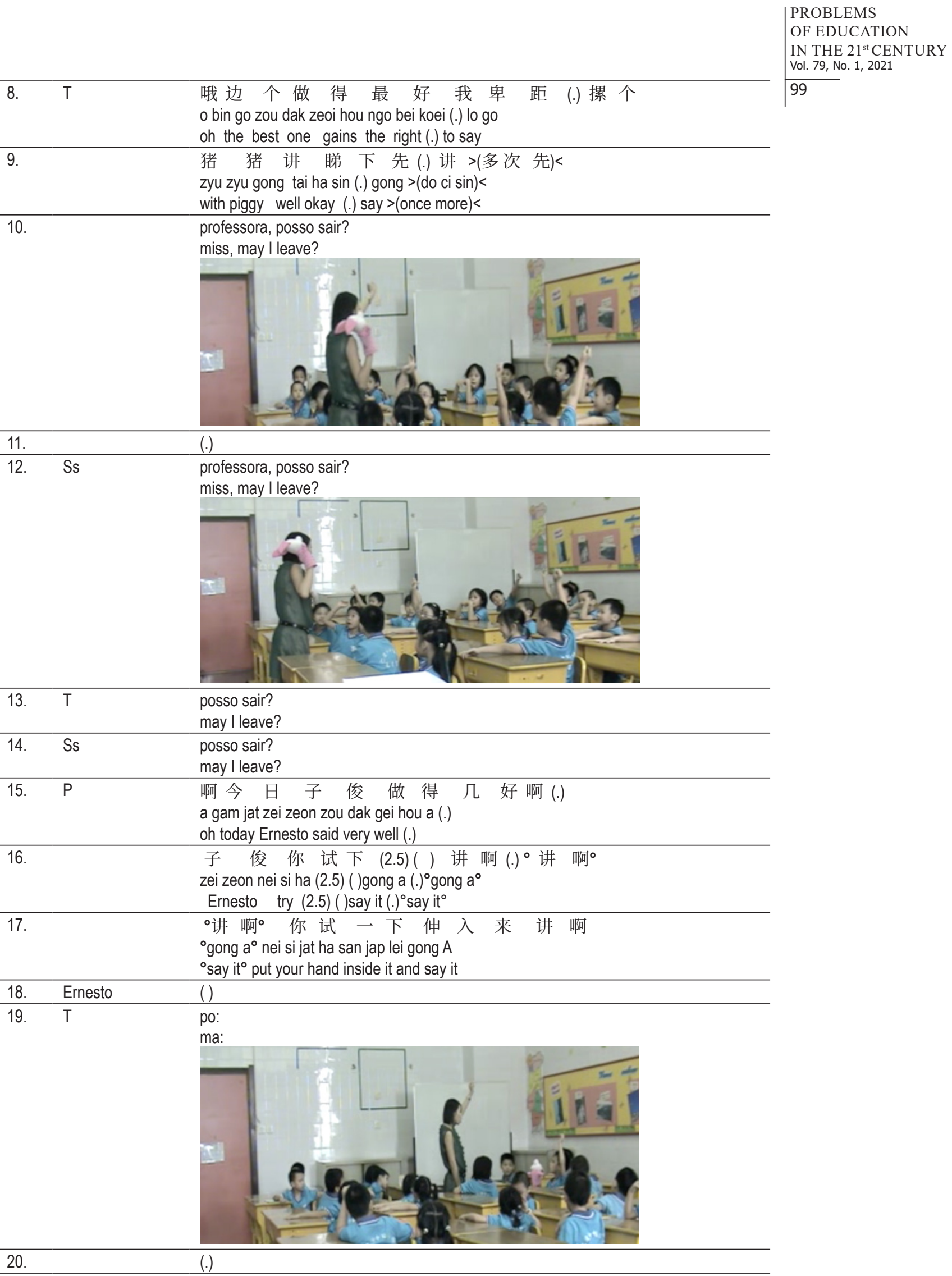


PROBLEMS

OF EDUCATION

IN THE $21^{\text {st }}$ CENTURY

Vol. 79 , No. 1,2021

$$
100
$$

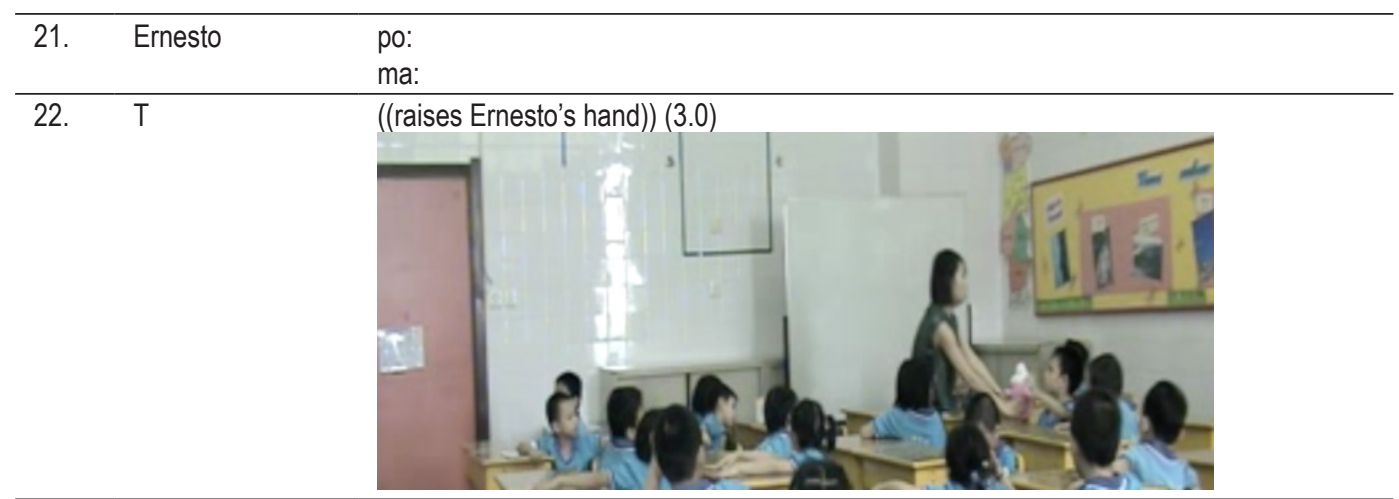

23.

哎呀哎呀唔记得左哦 (.)点 讲 啊?

ai ya ai ya $\mathrm{m}$ gei dak zo o (.) dim gong a?

oh oh he forgot (.) how to say it?

\begin{tabular}{lll}
\hline 24. & Joana & $\begin{array}{l}\text { professora, posso sair? } \\
\text { miss, may l leave? }\end{array}$ \\
\hline 25. & T & ((shoves the puppet in Gabriel's hands)
\end{tabular}



profe[ssora

mi[ss

[posso sair?

[may I leave?

系 啦 (.) posso sair?=

hai la (.)

yes (.) may l leave?=

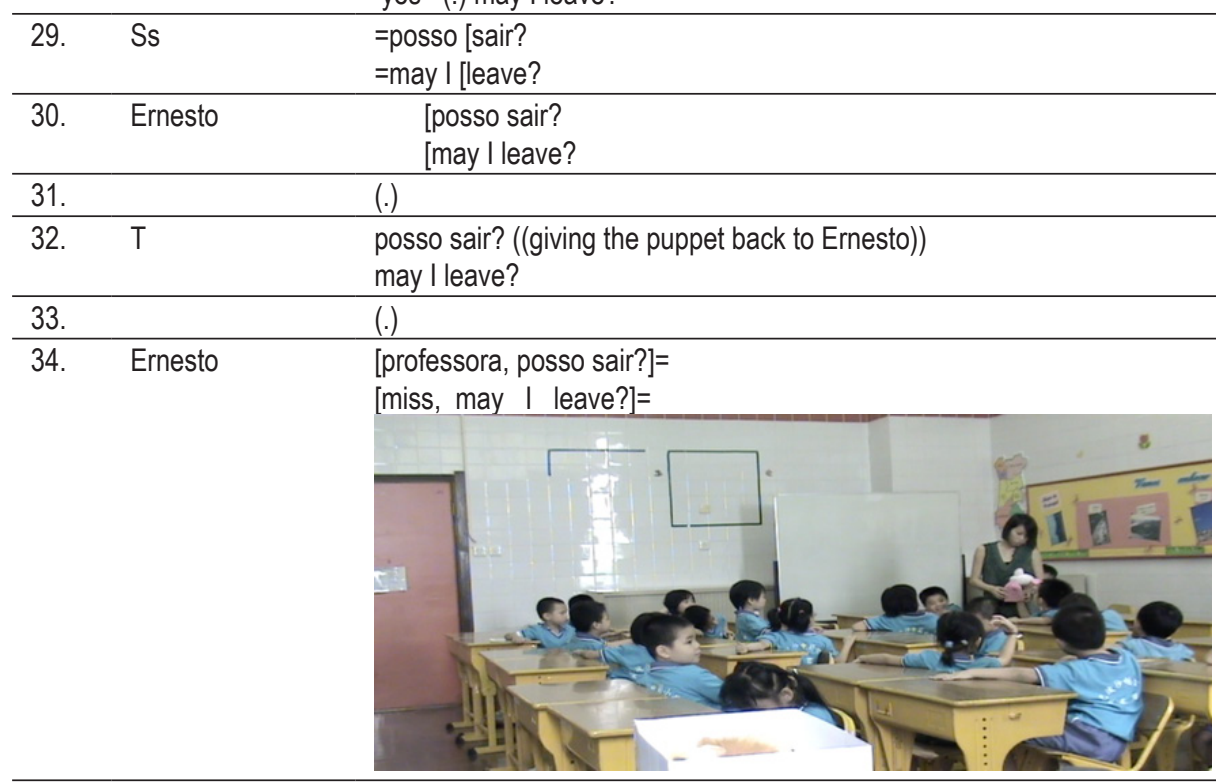




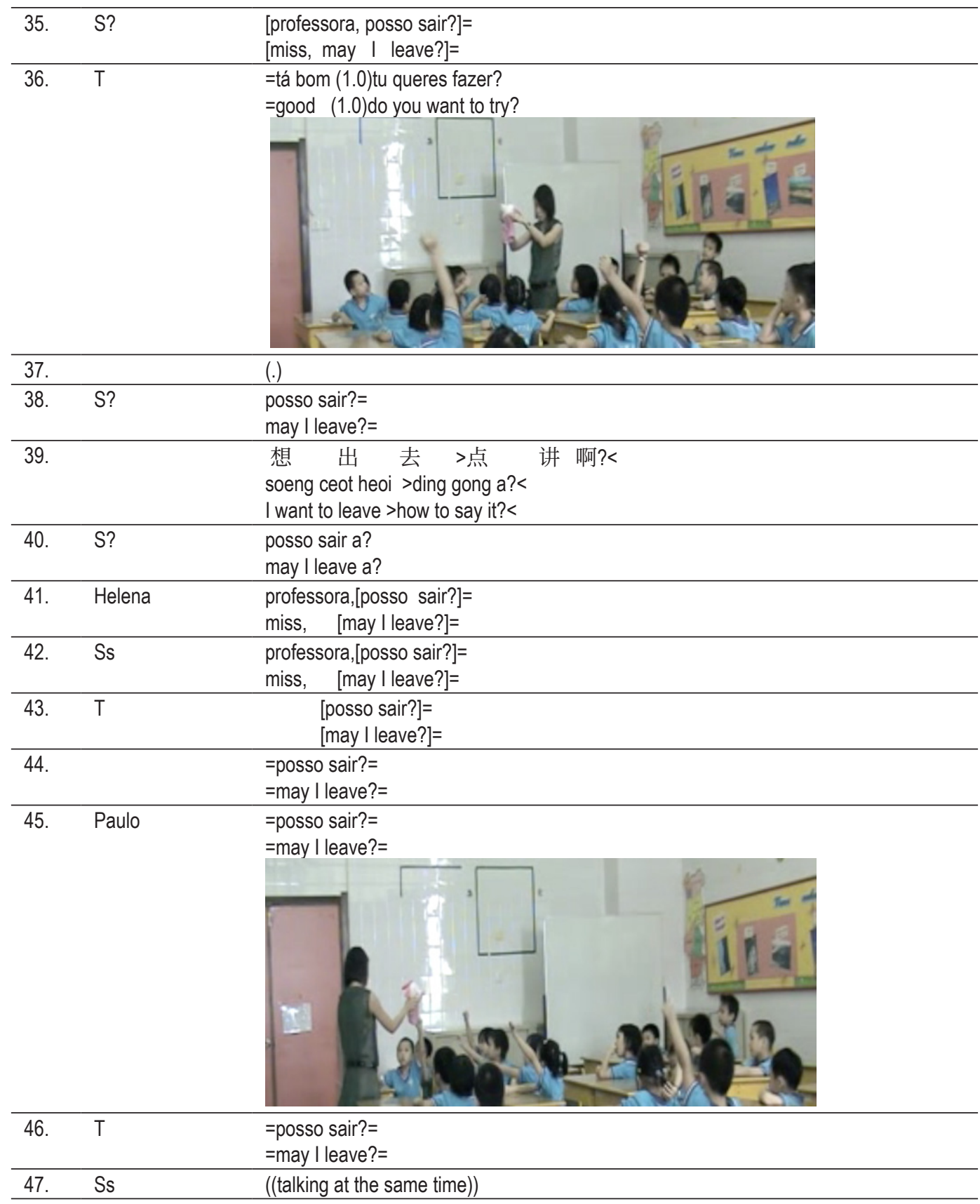


PROBLEMS

OF EDUCATION

IN THE $21^{\text {st }}$ CENTURY Vol. 79 , No. 1,2021

102

\section{Appendix B - Transcription Conventions}

\begin{tabular}{ll}
\hline$()$. & No timed pause \\
\hline$(2,3)$ & Timed pause \\
\hline$(\ldots)$ & Unintelligible \\
\hline$?$ & Rising intonation \\
\hline & Falling intonation \\
\hline underlined & Continuing intonation \\
\hline CAPITAL & Stress \\
\hline hh & Heavy stress (usually when the speech is louder than the surrounding discourse) \\
\hline hahaha & Out-breaths; the more "h's" the longer the out-breath; each "h" is of about 0.1 second's duration \\
\hline 'word & Laughter; the more "ha's" the longer the laughter \\
\hline$:$ or :: & Soft stress (usually when the speech is lower than the surrounding discourse) \\
\hline[ & Prolonging of the preceding sound or syllable \\
\hline$]$ & Beginning of an overlapping talk \\
\hline (word) & End of an overlapping talk \\
\hline$(($ word) $)$ & Questionable words \\
\hline 'word' & Researcher' comments or aspects of the utterance (such as whispers or coughing) \\
\hline & Reported speech \\
\hline
\end{tabular}

\section{Notes}

${ }^{1}$ Watson further refines category-analysis - the use of rules for the application of categories - with the development of 'turn-informed categories' (Watson 2015). However, the data presented in this paper do not withstand the analytic burden of 'turn-informed categories' pro tem. In order to preserve the phenomenological integrity of these data, attention is drawn to its turn-allocational character. This is an example of how we orient to the recording as data mentioned in the Research Focus and Methodology sections: the data take precedence over extant literature.

${ }^{2}$ Partipants in the class are familiar with a range of classroom activities, such as their being part of a class, sitting down at desks, and recognizing the status of 'teacher' of that class. Raising a hand in order to ask permission to leave is commonly known among the participants in that class; students seem to have no problems in recognizing this gesture and combining it with the utterance they were practicing in the target language.

${ }^{3}$ The discovery of practical competence points to a specific category 'the best student' in a way that the participants of that classroom share the same commonsense knowledge about what constitutes the best student. However, they are able to do so not just because they are present in that classroom, but because they are engaged in the objective production and display of that commonsense knowledge.

Received: September 23, 2020

Accepted: January 20, 2021 
Cite as: Moutinho, R., \& Carlin, A. P. (2021). 'Learning moments' as inspectable phenomena of inquiry in a second language classroom. Problems of Education in the 21st Century, 79(1), 80-103. https://doi.org/10.33225/pec/21.79.80

Ricardo Moutinho

(Corresponding author)
$\mathrm{PhD}$, Associate Professor, University of Macau, Faculty of Arts and Humanities, Department of Portuguese; Research Fellow, Institute of Advanced Studies in Humanities and Social Sciences, E21-3076, Av. da Universidade, Taipa, Macau.

E-mail: moutinho@umac.mo

ORCID: https://orcid.org/0000-0002-9625-1116

Andrew P. Carlin
PhD, Research Fellow, University of Macau, Faculty of Arts and Humanities, Department of Portuguese, E21-3076, Av. da

Universidade, Taipa, Macau.

E-mail: acarlin@um.edu.mo

ORCID: https://orcid.org/0000-0001-5138-9384 